\title{
Self-Esteem and Body Appreciation in Students of Sports Sciences Faculty: A Structural Equation Model
}

\author{
Okan Burçak Çelik ${ }^{1} \&$ Nuri Berk Güngör ${ }^{2}$ \\ ${ }^{1}$ Faculty of Sports Sciences, Gazi University, Ankara, Turkey \\ ${ }^{2}$ School of Physical Education and Sports, Karamanoğlu Mehmetbey University, Karaman, Turkey \\ Correspondence: Okan Burçak Çelik, Faculty of Sports Sciences, Gazi University, Ankara, 06560, Turkey. E-mail: \\ okanburcakcelik@gmail.com
}

Received: March 20, 2020

Accepted: April 25, 2020

Online Published: June 5, 2020

doi:10.5539/ies.v13n7p31

URL: https://doi.org/10.5539/ies.v13n7p31

\begin{abstract}
The aim of this research is to examine the body appreciation and self-esteem levels of sports sciences faculty students. In this study, it was used relational screening model that is one of the quantitative reserch methods. The research group of the study was composed of students who study in Faculty of Sports Sciences in Gazi University. In study, Rosenberg Self-Esteem Scale (RSES) and Body Appreciation Scale (BAS) were used as data collection tools. The Pearson Moments Product Correlation, structural equation model and path analysis independent sample t-test, one-way ANOVA, percentage, frequency and descriptive statistics were used in data analysis. As a result of the research, it was determined that the self-esteem of students of sports sciences faculty is at an average level. In addition, it was found that the level of participants' appreciating their own body was high. Moreover, it was concluded that self-esteem of female participants was higher than male participants, athletes in team sports has higher self-esteem than athletes in individual sports, 40-55 kg participants had a higher body appreciation score than 101 and over kg participants. Finally, it was concluded that the level of body appreciation increases as the level of self-esteem increases. As a conclusion of this study, it can be said that higher body appreciation correlated with higher self-esteem.
\end{abstract}

Keywords: body appreciation, self-esteem, university students

\section{Introduction}

It can be said that one of the keys to leading a happy life is that human accept and value himself. To be perfect for a person is not possible. Therefore, giving himself the necessary value and accepting himself with all his flaws can increase the self-esteem of the person. It may be appropriate to explain this situation with the concept of self-esteem. In daily life, As a result of self-evaluation on issues such as clothing, thoughts, interests, conversation style, relationships with different people, the level of appreciation reached by the person about himself expresses self-esteem (Gül, 2013). Self-esteem is generally defined as the evaluative dimension of the concept of self. It is examined as a psychological state of self-evaluation on a scale ranging from positive to negative (Hewitt, 2002).

In addition, people's perceptions of how they look and body they have (body image or body appreciation) can be shown as a factor associated with self-esteem. Body image is a versatile structure that refers to the perceptions and attitudes of individuals about their bodies, especially their appearance (Cash, Fleming, Alindogan, Steadman, \& Whitehead, 2002). Every person has a mental picture of his own body, known as the body image. Body image seems to be determined by interpersonal, environmental and cultural factors. At birth, individuals do not have a body image, but as they gradually become aware of their body, body images of them develop (Münstedt, Manthey, Sachsse, \& Vahrson, 1997). It has been stated by some researchers that individuals' body images are related to self-esteem. Oney, Cole, and Sellers (2011) stated that there is a negative relationship between body dissatisfaction and self-esteem for both women and men. Jeong and Park (2007) expressed that there is a moderate positive relationship between body image and self-esteem. Baker and Gringart (2009) emphasized that body-image anxiety is important for self-esteem in old age. Mellor, Fuller-Tyszkiewicz, McCabe and Ricciardelli (2010) concluded that high self-esteem is associated with low body dissatisfaction.

Considering these, it would not be wrong to say that sports help to have a more beautiful body, thus improving the body image. However, Hausenblas and Fallon (2007) stated that exercise is associated with an improved body 
image. In addition, Abbot and Barber (2011) expressed that sports participants have a higher functional body image than those who are not physically active. It can be interpreted from past studies that positive body image improves self-esteem, and sports contribute to positive body image and thus positive self-esteem.

As can be seen from previous studies, it can be said that there is a relationship between body image and self-esteem. People often look in the mirror and examine their bodies. When faced with a situation in which they are not satisfied, they make an effort to hide it in their daily lives. They don't want that their friends or the people around them see that. Considering these, it is thought that high perception of body image increase self-esteem. In this context, this study aims to examine the body appreciation and self-esteem levels of sports sciences faculty students.

\section{Method}

In this chapter; information on the research model, the research group, the data collection tool and the analysis of the data was presented.

\subsection{Research Model}

In this study, it was used relational screening model. Relational screening model is used to determine the relationship between two or more variables and to obtain clues about cause and effect (Karasar, 2017). As a result of the literature review, the model of the research was created based on the variables used in the research. The model was tested by using the structural equation model. Structural equation is a combination of factor analysis and regression analysis and is a theoretical structure represented by latent and observed variables (Şimşek, 2007). As a result of the literature review, the hypotheses of the model created in accordance with the purpose of the research are given below.

$\mathrm{H}_{1}$ : Self-esteem positively affects the body appreciation level.

\subsection{Research Group}

The research group of the study was composed of students who study in Faculty of Sports Sciences in Gazi University.

Table 1. Demographic information of the participants

\begin{tabular}{cccc}
\hline Participants & Variables & $\mathrm{N}$ & $\%$ \\
\hline \multirow{2}{*}{ Gender } & Male & 220 & 49.2 \\
\cline { 2 - 4 } & Female & 227 & 50.8 \\
\hline \multirow{2}{*}{ Branch of sports } & Individual Sports & 159 & 35.6 \\
& Team Sports & 288 & 64.4 \\
\hline \multirow{3}{*}{ Body weight } & $40-55 \mathrm{Kg}$ & 132 & 29.5 \\
\cline { 2 - 4 } & $56-70 \mathrm{Kg}$ & 160 & 35.8 \\
& $71-85 \mathrm{Kg}$ & 114 & 25.5 \\
& $86-101 \mathrm{Kg}$ & 30 & 6.7 \\
& $102 \mathrm{Kg}$ and Above & 11 & 2.5 \\
\hline & Total & 447 & 100 \\
\hline
\end{tabular}

\subsection{Data Collection Tools}

\section{1) Rosenberg Self-Esteem Scale (RSES)}

The original form of the scale was developed by Rosenberg (1965) and adapted to Turkish by Çuhadaroğlu (1986). It consists of 63 items and 12 sub-dimensions in total. In line with the purpose determined for this research, the 10-item self-esteem subscale was used. In this form of the scale; Items 1, 2, 4, 6 and 7 are positive, items 3, 5, 8, 9 and 10 are negative. The scale, which has a 4-point Likert structure, is structured with the expressions "very correct", "correct", "wrong" and "very wrong". The high score obtained from the scale means low self-esteem and is low score means high self-esteem. Cronbach Alpha reliability coefficient obtained from the data set was determined as .85 .

\section{2) Body Appreciation Scale (BAS)}

The scale, developed by Tylka and Wood-Barcalow (2015), was adapted to Turkish by Anl, Akın, Eker and Özçelik (2015) by conducting a validity and reliability study. The scale is 5-point Likert type and consists of 10 items in total. All items in the scale are positive and are graded with the words "never", "seldom", "sometimes", 
"often" and "always". The high score obtained from the scale indicates that the body appreciation level is high, and the low score indicates that body appreciation level is low. Cronbach Alpha reliability coefficient obtained from the data set was determined as .94.

3) Confirmatory Factor Analysis Results of Measuring Instruments Used in the Study

Table 2. Self-esteem and body appreciation scales confirmatory factor analysis results

\begin{tabular}{ccccc}
\hline Model Fit Index & Perfect Range & Acceptable Range & RSES & BAS \\
\hline $\mathrm{X}^{2} / \mathrm{sd}$ & $0<\mathrm{X}^{2} / \mathrm{sd}<2$ & $2<\mathrm{X}^{2} / \mathrm{sd}<5$ & 4.68 & 3.01 \\
$\mathrm{RMSEA}$ & $0.00<\mathrm{RMSEA}<0.05$ & $0.05<\mathrm{RMSEA}<0.10$ & .08 & .07 \\
PGFI & $0.95<\mathrm{PGFI}<1.00$ & $0.50<\mathrm{PGFI}<0.95$ & .54 & .59 \\
PNFI & $0.95<\mathrm{PNFI}<1.00$ & $0.50<\mathrm{PNFI}<0.95$ & .65 & .73 \\
GFI & $0.90<\mathrm{GFI}<1.00$ & $0.85<\mathrm{GFI}<0.90$ & .93 & .95 \\
AGFI & $0.90<\mathrm{AGFI}<1.00$ & $0.85<\mathrm{AGFI}<0.90$ & .88 & .92 \\
CFI & $0.95<\mathrm{CFI}<1.00$ & $0.90<\mathrm{CFI}<0.95$ & .93 & .98 \\
\hline
\end{tabular}

First level confirmatory factor analysis was applied to test the construct validity of Self-Esteem Scale. In order to make the analysis results more compatible, the suggestions of Amos 22 package program were taken into consideration and covariance assignments were made between the e1-e2, e4-e5 and e9-e10 error terms. The fit index produced by the measurement model as a result of the application of the proposed modifications is given in Table 2. First level confirmatory factor analysis was applied to test the construct validity of Body Appreciation Scale. To make the analysis results more compatible, covariance assignments were made between the e3-e4 error terms. Since the goodness of fit values stated in Table 2 are at an acceptable level, the single-factor structures of the measuring instruments used in the study were confirmed (Meydan \& Şeşen, 2011).

\subsection{Data Analysis}

Before starting the analysis of the data, 15 forms filled out incorrectly or incompletely were removed from the dataset. Then, Shapiro Wilk test was applied to determine whether the data had normal distribution and it was concluded that the data set has a normal distribution by considering the kurtosis and skewness values. For this reason, parametric tests were used in the analysis of the data.

The Pearson Moments Product Correlation was used to determine the relationship between the participants' self-esteem and body appreciation levels. In addition, the predictive role of the participants' self-esteem on their body appreciation levels was tested by using the structural equation model and path analysis. In addition, T-Test, One-Way Anova, percentage, frequency and descriptive statistics were used in the study.

In this study, data were analyzed using SPSS 22.0, AMOS 22.0 package programs and Excel database program.

\section{Results}

In this section, the findings obtained by analyzing the data are presented in tables.

Table 3. Self-esteem and body appreciation scores of participants

\begin{tabular}{cccc}
\hline Scales & $\mathrm{N}$ & $\overline{\mathrm{X}}$ & $\mathrm{S}$ \\
\hline Self-Esteem Scale & 447 & 1.98 & .43 \\
Body Appreciation Scale & 447 & 4.09 & .81 \\
\hline
\end{tabular}

Considering the average score $(\overline{\mathrm{X}}=1.98)$ obtained by the participants from the Self-Esteem Scale, it can be stated that their self-esteem is at an average level. In addition, participants' body appreciation score $(\bar{X}=4.09)$ shows that the their body appreciation level is high. 
Table 4. T-test showing self-esteem and body appreciation score of participants by gender

\begin{tabular}{|c|c|c|c|c|c|c|c|}
\hline Scales & Gender & $\mathrm{N}$ & $\overline{\mathrm{X}}$ & $\mathrm{S}$ & $\mathrm{sd}$ & $\mathrm{t}$ & $\mathrm{p}$ \\
\hline \multirow{2}{*}{ RSES } & Female & 220 & 1.95 & .40 & \multirow{2}{*}{445} & \multirow{2}{*}{1.77} & \multirow{2}{*}{.04} \\
\hline & Male & 227 & 2.02 & .47 & & & \\
\hline \multirow{3}{*}{ BAS } & Female & 220 & 4.09 & .86 & \multirow{2}{*}{445} & \multirow{2}{*}{.15} & \multirow{2}{*}{.45} \\
\hline & Male & 227 & 4.09 & .79 & & & \\
\hline & Total & 447 & & & & & \\
\hline
\end{tabular}

When Table 4 is examined, it is seen that the self-esteem score of female participants is $\bar{X}=1.95$ and the score of male participants is $\bar{X}=2.02$. The results of the analysis indicate that there is a statistically significant difference in favor of female participants, $\mathrm{t}(445)=1.77, \mathrm{p}<.05$. However, body appreciation scores of both male and female participants were determined as $\bar{x}=4.09$. The results of the analysis indicate that the body appreciation level of the participants does not differ significantly according to the gender variable, $t(445)=.15, \mathrm{p}>.05$.

Table 5. T-Test showing self-esteem and body appreciation score of participants by sports branch

\begin{tabular}{|c|c|c|c|c|c|c|c|}
\hline Scales & Sports Branch & $\mathrm{N}$ & $\overline{\mathrm{X}}$ & $S$ & $\mathrm{sd}$ & $\mathrm{t}$ & $\mathrm{p}$ \\
\hline \multirow{2}{*}{ RSES } & Individual & 159 & 2.06 & .52 & \multirow{2}{*}{445} & \multirow{2}{*}{2.96} & \multirow{2}{*}{.00} \\
\hline & Team & 288 & 1.94 & .38 & & & \\
\hline \multirow{3}{*}{ BAS } & Individual & 159 & 4.09 & .86 & \multirow{2}{*}{445} & \multirow{2}{*}{.10} & \multirow{2}{*}{.61} \\
\hline & Team & 288 & 4.08 & .79 & & & \\
\hline & Total & 447 & & & & & \\
\hline
\end{tabular}

The average self-esteem score of participants who are involved in individual sports is determined as $\overline{\mathrm{X}}=2.06$, and the average score of participants who are involved in team sports is determined as $\bar{X}=1.94$. Analysis results show that participants who involve in team sports have higher self-esteem than those who involve in individual sports, $\mathrm{t}(445)=-2.96, \mathrm{p}<.05$. The average body appreciation score of the participants who involve in individual sports is determined as $\bar{X}=4.09$, and the average score of those who involve in team sports is determined as $\bar{X}=4.08$. The results of the analysis indicate that the body appreciation level of the participants did not differ significantly according to the type of sports branch, $\mathrm{t}(445)=.10, \mathrm{p}>.05$.

Table 6. One Way ANOVA test showing self-esteem and body appreciation score of participants by body weight

\begin{tabular}{ccccccc}
\hline Scales & Body Weight & $\mathrm{N}$ & $\overline{\mathrm{X}}$ & $\mathrm{SS}$ & $\mathrm{F}$ & $\mathrm{p}$ \\
\hline \multirow{6}{*}{ RSES } & $40-55 \mathrm{Kg}$ & 132 & 1.96 & .40 & & \\
& $56-70 \mathrm{Kg}$ & 160 & 2.04 & .46 & & \\
& $71-85 \mathrm{Kg}$ & 114 & 1.97 & .47 & & \\
& $86-101 \mathrm{Kg}$ & 30 & 1.92 & .35 & & .39 \\
& $101 \mathrm{Kg}$ ve above & 11 & 1.95 & .27 & & \\
& Total & 447 & 1.99 & .44 & & \\
\hline \multirow{6}{*}{ BAS } & $40-55 \mathrm{Kg}$ & 132 & 4.24 & .70 & & \\
& $56-70 \mathrm{Kg}$ & 160 & 3.99 & .84 & & \\
& $71-85 \mathrm{Kg}$ & 114 & 4.08 & .89 & & \\
& $86-101 \mathrm{Kg}$ & 30 & 4.20 & .63 & 3.87 & .004 \\
& $101 \mathrm{Kg}$ ve above & 11 & 3.40 & .96 & & \\
& Total & 447 & 4.09 & .82 & & \\
\hline
\end{tabular}

When the average self-esteem score of the participants was examined, it was determined that the participants with the highest self-esteem level are those in the range of 86-100 kg according to the body weight variable. 160 participants in the range of 56-70 kg have the lowest self-esteem level. The results of the analysis indicate that the self-esteem scores of the participants did not differ significantly according to the body weight variable, $F(4$, $442)=1.03, \mathrm{p}>.05$.

It is seen that 132 participants in the range of $40-55 \mathrm{~kg}$ have highest average body appreciation score according to 
the body weight variable. The lowest average score belongs to 11 participants in the range of $101 \mathrm{~kg}$ and above. The results of the analysis show that there is a statistically significant difference between participants' body appreciation score and body weight variable, $\mathrm{F}(4,442)=3.87, \mathrm{p}<.05$. The Tukey test was conducted to determine which groups were significantly different, and the body appreciation level of the participants in the $40-55 \mathrm{~kg}$ range was found statistically higher than those in the $101 \mathrm{~kg}$ and above.

Table 7. Correlation of the Pearson Moments Product, which shows the relationship between self-esteem and appreciation of the body

$\mathrm{p}<.01$.

\begin{tabular}{cc}
\hline Variables & Body Appreciation \\
\hline Self-Esteem & $-.538^{* *}$ \\
\hline
\end{tabular}

When Table 7 is examined, it is seen that there is a negative and moderate relationship between the participants' self-esteem average score and their body appreciation average score, $(\mathrm{r}=-.538, \mathrm{p}<.01)$.

After examining the relationship between the latent and observed variables of the study, the predictive effect of the "self-esteem" variable on the "body appreciation" variable was tested by path analysis.

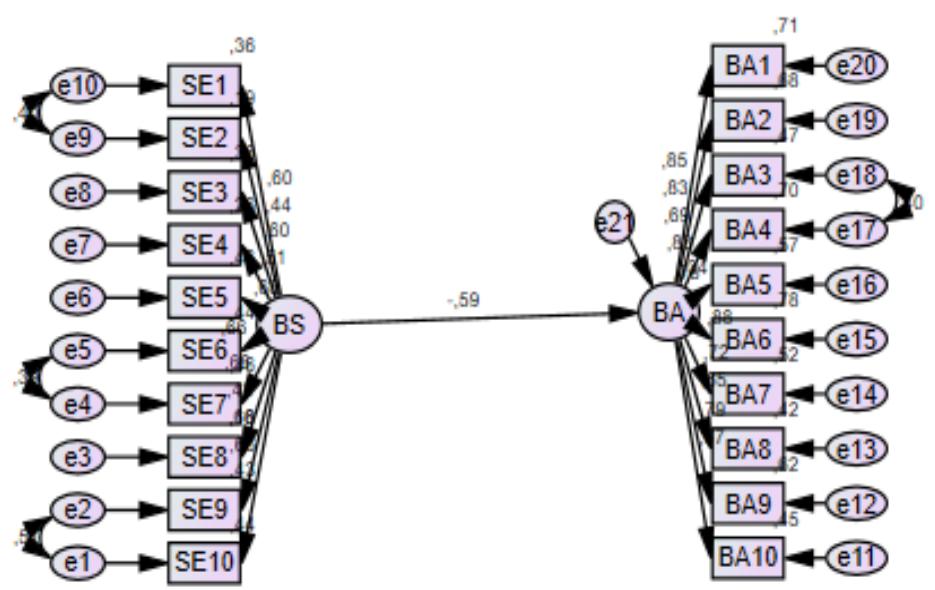

Figure 1. Structural equation model

The fit indexes of the model presented in Figure 1 are given in Table 9.

Table 8. Structural equation model goodness of fit values

\begin{tabular}{cccc}
\hline Model Fit Index & Perfect Range & Acceptable Range & SEM \\
\hline $\mathrm{X}^{2} / \mathrm{sd}$ & $0<\mathrm{X}^{2} / \mathrm{sd}<2$ & $2<\mathrm{X}^{2} / \mathrm{sd}<5$ & 2.86 \\
RMSEA & $0.00<\mathrm{RMSEA}<0.05$ & $0.05<\mathrm{RMSEA}<0.10$ &, 06 \\
PGFI & $0.95<\mathrm{PGFI}<1.00$ & $0.50<\mathrm{PGFI}<0.95$ &, 70 \\
PNFI & $0.95<\mathrm{PNFI}<1.00$ & $0.50<\mathrm{PNFI}<0.95$ &, 87 \\
GFI & $0.90<\mathrm{GFI}<1.00$ & $0.85<\mathrm{GFI}<0.90$ &, 90 \\
AGFI & $0.90<\mathrm{AGFI}<1.00$ & $0.85<\mathrm{AGFI}<0.90$ &, 87 \\
$\mathrm{CFI}$ & $0.95<\mathrm{CFI}<1.00$ & $0.90<\mathrm{CFI}<0.95$ &, 94 \\
\hline
\end{tabular}

When Table 8 is examined, it is seen that the model provides the necessary goodness of fit values and the model is confirmed. In other words, the data obtained with the established model has achieved a sufficient level of compliance $\left(\mathrm{x}^{2} / \mathrm{sd}=2.86, \mathrm{RMSEA}=.06, \mathrm{PGFI}=.70, \mathrm{PNFI}=.87, \mathrm{GFI}=.90, \mathrm{AGFI}=.87, \mathrm{CFI}=.94\right)$. After examining 
the goodness of fit index values for the model, the paths in the model and the parameter estimates for the model were examined. According to the model created, the standardized $\beta$ coefficients, standard error, critical ratio, $p$ and $\mathrm{R}^{2}$ values between the variables were shown in Table 8 .

Table 9. Structural equation model results

\begin{tabular}{cccccc}
\hline Variables & Standardized $\beta$ & Standard Error & Critical Ratio & $\mathrm{p}$ & $\mathrm{R}^{2}$ \\
\hline Self-Esteem \& Body Appreciation & -.59 & .12 & -9.87 & $* * *$ & .35 \\
\hline
\end{tabular}

When the results of the analysis are examined, a significant effect was found in the relationship of self-esteem with body appreciation $(\beta=-.59 ; \mathrm{p}<.05)$. According to the findings obtained, the hypothesis number 1 of the study was accepted. When the Squared Multiple Correlations $\left(\mathrm{R}^{2}\right)$ value of the model is examined, it is seen that $35 \%$ of body appreciation is explained.

\section{Discussion}

As a result of the research, it was determined that the self-esteem of students of sports sciences faculty is at an average level. Aktaş et al. (2018) found that self-esteem level of participants is at moderate-high level. Sarıbaş et al. (2019) stated that the participants had moderate self-esteem. Results of current study shows similarity with results of the other studies. It is seen that sample groups of both current study and other studies are similar. Therefore, it can be interpreted that the results of studies are similar.

In another result of the research, it was found that the level of participants' appreciating their own body was high. When other studies are examined, it is seen that Abakay, Alicak, and Ay (2017) emphasized that body perception level of the participants was high. Similarly, Öztürk et al. (2018) stated in their study that the level of being pleased with their body image of participants was above average. Results of current study shows similarity with results of the other studies. When both current and other studies are examined in detail, it is seen that they study young people. From this point of view, it can be interpreted that the level of young people's appreciation of their bodies is above average or high.

In research, it was determined that self-esteem of female participants was higher than male participants. Arshad, Zaidi \& Mahmood (2015) found that males had higher self-esteem than females. Kim et al. (2002) expressed that females reported lower self-esteem than males. Similarly, McMullin and Cairney (2004) reported that women have lower levels of self-esteem than men in all age group. Results of current study do not show similarity with results of the other studies. Women's role in life can vary from culture to culture. While they take a backseat in some societies, they come into prominence in some societies. For this reason, it can be considered normal that the results of the research differ from each other.

As a result of the research, it was concluded that there is no difference between male and female participants in level of appreciating their own body. When previous studies are examined, it is seen that there is similar and different conclusions. Marta-Simões et al. (2016) stated that body appreciation didn't differ among genders. This conclusion shows similarity with conclusion of current study. Swami et al. (2008) expressed that men body appreciation scores are more positively than women. Also, Hill et al. (2016) indicated that women's body appreciation score is lower than men. Conclusions of these studies do not show similarity with conclusion of the current study. Today, it would not be wrong to say that women pay attention to their physical appearance as much as men. It can say that this situation is similar in Turkey. Therefore, as a result of the research, the body appreciation level of women could have been found higher.

In this study, it was found that athletes in team sports have higher self-esteem than athletes in individual sports. When past studies are examined, it is seen that Yegül and Koruç (1997) concluded that there is no difference between elite athletes in team sports and in individual sports on self-esteem. Also in contrary to current study, Atan et al. (2018) stated that athletes in individual sports have higher self-esteem than athletes in team sports. Although different results may occasionally be encountered in the literature, it can be said that athletes engaged in team sports have strong social relationships. Also, Doğan, Totan, and Sapmaz (2009) stated that as social intelligence increases, self-esteem also increases. It can be interpreted that the reason of the difference between the participants is social intelligence.

According to results of the current study, it was concluded that there is no difference between athletes in team and individual sports. When literature was examined, it was determined that Morano et al. (2010) emphasized athletes in individual sports reported higher body dissatisfaction compared with athletes in team sports. When it is thought 
that athletes have regular training and nutrition programs, it is likely that their physical appearance is good. For this reason, the absence of a difference between the participants can be interpreted as normal. All participants of current study are athlete. It is likely that Athletes have some success in their career. It can be expected that the sense of success will increase self-esteem. This may be why there is no difference between the participants.

In the study, it was concluded that the scores that the participants got from the Self-Esteem Scale did not differ significantly based on their body weight. When previous studies are examined, it was determined that O'dea (2006) found that heavier weight girls had lower self-esteem than low weight girls. Also, it was seen that Van Den Berg et al. (2010) concluded that obese participants have lower self-esteem in both males and females. Likewise, Tiggermann (2005) determined that young girls with perceptions of being overweight were particularly defenceless to developing low self-esteem. To be an athlete means struggling and succeeding. It is likely that successful persons have higher self-esteem. Absence of difference between participants can be interpreted like that.

As a result of the research, it was determined that 40-55 kg participants had a higher body appreciation score than 101 and over kg participants. Similarly, Tyler et al. (2009) stated that increased body weight was correlated with higher levels of body dissatisfaction. Likewise, Kantanista et al. (2015) indicated that higher BMI was correlated with more negative body image. Along the same line, Algars et al. (2009) expressed that a higher BMI was correlated to more body dissatisfaction in both gender. Nobody wants to be or appear overweight. It would not be wrong to say that overweight affects the physical appearance. For this reason, it can be seen normal that less weight people appreciate their bodies according to people with more weight.

In the study, it was concluded that the level of body appreciation increases as the level of self-esteem increases. When literature was examined, it is seen that Lobera and Rios (2011) indicated that there is positive and significant relationship between body appreciation and self-esteem. Similarly, Mäkinen et al. (2012) expressed body dissatisfaction and self-esteem was negatively correlated. Likewise, Mellor et al. (2010) stated that lower body dissatisfaction correlated with higher self-esteem. In addition, Olivardia et al. (2004) determined that participants in their study showed significant body dissatisfaction and that this body dissatisfaction is closely correlated with low self-esteem. Moreover, Dorak (2011) found that there was a moderately positive correlation between self-esteem and body image in their participants. Results of current study shows similarity with results of the other studies. In addition, individuals feel valuable and respect themselves, believe that they have positive characteristics, think that they have sufficient equipment and are successful; It can be stated that they respect their body status and feel positive about this subject, they love different features of their bodies, and their perception of feeling beautiful and peaceful.

\section{References}

Abakay, U., Alıncak, F., \& Ay, S. (2017). Üniversite öğrencilerinin beden algıSı ve atılganlık düzeylerinin incelenmesi. Uluslararası Türk Eğitim Bilimleri Dergisi, 2017(9), 12-18. Retrieved from https://dergipark.org.tr/en/pub/goputeb/issue/34356/379543

Abbott, B. D., \& Barber, B. L. (2011). Differences in functional and aesthetic body image between sedentary girls and girls involved in sports and physical activity: Does sport type make a difference? Psychology of Sport and Exercise, 12(3), 333-342. https://doi.org/10.1016/j.psychsport.2010.10.005

Aktaş, M.C., Bulduk, B., Çelik, D., \& Ensarioğlu, K. (2018). Hemşirelik öğrencilerinde benlik saygısı ve empatik düzey arasındaki ilişkinin çeşitli değişkenlere göre değerlendirilmesi. Hemşirelik Bilimi Dergisi, 1(3), 21-26. Retrieved from https://dergipark.org.tr/en/pub/hbd/issue/43003/516206

Algars, M., Santtila, P., Varjonen, M., Witting, K., Johansson, A., Jern, P., \& Sandnabba, N. K. (2009). The adult body: how age, gender, and body mass index are related to body image. Journal of Aging and Health, 21(8), 1112-1132. https://doi.org/10.1177/0898264309348023

Anli, G., Akin, A., Eker, H., \& Ozcelik, B. (2015). The validity and reliability of Turkish version of the Body Appreciation Scale. The Journal of Academic Social Science Studies, 36, 505-511. http://dx.doi.org/10.9761/JASSS2906

Arshad, M., Zaidi, S. M. I. H., \& Mahmood, K. (2015). Self-esteem \& academic performance among university students. Journal of Education and Practice, 6(1), 156-162. Retrieved from https://www.iiste.org/Journals/index.php/JEP/article/view/22058

Atan, T., Ünver, Ş., \& Allahverdi, E. (2018). Üniversitede öğrenim gören sporcuların ve sedanterlerin benlik saygısı düzeylerinin karşılaştırılması. CBÜ Beden Eğitimi ve Spor Bilimleri Dergisi, 13(1), 125-135. Retrieved from https://dergipark.org.tr/en/pub/cbubesbd/issue/38083/399102 
Baker, L., \& Gringart, E. (2009). Body image and self-esteem in older adulthood. Ageing \& Society, 29(6), 977-995. https://doi.org/10.1017/S0144686X09008721

Cash, T. F., Fleming, E. C., Alindogan, J., Steadman, L., \& Whitehead, A. (2002). Beyond body image as a trait: The development and validation of the Body Image States Scale. Eating Disorders, 10(2), 103-113. https://doi.org/10.1080/10640260290081678

Çuhadaroğlu, F. (1986). Adolesanlarda benlik saygısı. Uzmanlık Tezi, Hacettepe Üniversitesi Tıp Fakültesi Psikiyatri Bölümü, Ankara.

Doğan, T., Totan, T., \& Sapmaz, F. (2013). Üniversite öğrencilerinde benlik saygısı ve sosyal zeka. Sakarya Üniversitesi Eğitim Fakültesi Dergisi, 17, 235-247. Retrieved from https://dergipark.org.tr/tr/pub/sakaefd/issue/11213/133922

Dorak, F. (2011). Self-esteem and body image of Turkish adolescent girls. Social Behavior and Personality: An International Journal, 39(4), 553-561. https://doi.org/10.2224/sbp.2011.39.4.553

Gül, H. (2013). Investigation of undergraduate student's self-esteem levels in terms of some variables. Hacettepe University Journal of Education, 28(2), 194-205. Retrieved from http://www.efdergi.hacettepe.edu.tr/shw_artcl-176.html

Hausenblas, H. A., \& Fallon, E. A. (2006). Exercise and body image: A meta-analysis. Psychology and Health, 2l(1), 33-47. https://doi.org/10.1080/14768320500105270

Hewitt, J. P. (2002). The social construction of self-esteem. In C. R. Snyder, \& S. J. Lopez (Eds.), Handbook of positive psychology (pp. 135-147). London: Oxford University Press.

Hill, B. M., Ogletree, S. M., \& McCrary, K. M. (2016). Body modifications in college students: Considering gender, self-esteem, body appreciation, and reasons for tattoos. College Student Journal, 50(2), 246-252. Retrieved from https://www.ingentaconnect.com/contentone/prin/csj/2016/00000050/00000002/art00013\# expand/collapse

Jeong, K. S., \& Park, G. J. (2007). Relationships among body image, self-esteem and health promotion behavior in mastectomy patients. Asian Oncology Nursing, 7(1), 36-46. Retrieved from http://www.koreascience.or.kr/article/JAKO200733155710013.page

Kantanista, A., Osiński, W., Borowiec, J., Tomczak, M., \& Król-Zielińska, M. (2015). Body image, BMI, and physical activity in girls and boys aged 14-16 years. Body image, 15, 40-43. https://doi.org/10.1016/j.bodyim.2015.05.001

Karasar, N. (2017). Scientific Research Method Concepts Principles Techniques. Ankara: 3A Ara.

Kim, O. S., Kim, S. W., \& Kim, A. J. (2002). BMI, weight control behavior, and self-esteem in high school adolescents. Journal of Korean Academy of Adult Nursing, 14(1), 53. Retrieved from https://www.koreamed.org/article/0094JKAAN/2002.14.1.53

Lobera, I. J., \& Ríos, P. B. (2011). Spanish version of the Body Appreciation Scale (BAS) for adolescents. The Spanish Journal of Psychology, 14(1), 411-420. https://doi.org/10.5209/rev_SJOP.2011.v14.n1.37

Mäkinen, M., Puukko-Viertomies, L. R., Lindberg, N., Siimes, M. A., \& Aalberg, V. (2012). Body dissatisfaction and body mass in girls and boys transitioning from early to mid-adolescence: additional role of self-esteem and eating habits. BMC psychiatry, 12(35), 1-8. https://doi.org/10.1186/1471-244X-12-35

Marta-Simões, J., Ferreira, C., \& Mendes, A. L. (2016). Exploring the effect of external shame on body appreciation among Portuguese young adults: The role of self-compassion. Eating Behaviors, 23, 174-179. https://doi.org/10.1016/j.eatbeh.2016.10.006

McMullin, J. A., \& Cairney, J. (2004). Self-esteem and the intersection of age, class, and gender. Journal of Aging Studies, 18(1), 75-90. https://doi.org/10.1016/j.jaging.2003.09.006

Mellor, D., Fuller-Tyszkiewicz, M., McCabe, M. P., \& Ricciardelli, L. A. (2010). Body image and self-esteem across age and gender: A short-term longitudinal study. Sex Roles, 63(9-10), 672-681. https://doi.org/10.1007/s11199-010-9813-3

Morano, M., Colella, D., \& Capranica, L. (2011). Body image, perceived and actual physical abilities in normal-weight and overweight boys involved in individual and team sports. Journal of Sports Sciences, 29(4), 355-362. https://doi.org/10.1080/02640414.2010.530678

Münstedt, K., Manthey, N., Sachsse, S., \& Vahrson, H. (1997). Changes in self-concept and body image during 
alopecia induced cancer chemotherapy. Supportive Care in Cancer, 5(2), 139-143. https://doi.org/10.1007/BF01262572

O'dea, J. A. (2006). Self-concept, self-esteem and body weight in adolescent females: A three-year longitudinal study. Journal of Health Psychology, 11(4), 599-611. https://doi.org/10.1177/1359105306065020

Olivardia, R., Pope Jr, H. G., Borowiecki III, J. J., \& Cohane, G. H. (2004). Biceps and body image: The relationship between muscularity and self-esteem, depression, and eating disorder symptoms. Psychology of Men \& Masculinity, 5(2), 112-120. https://psycnet.apa.org/doi/10.1037/1524-9220.5.2.112

Oney, C. N., Cole, E. R., \& Sellers, R. M. (2011). Racial identity and gender as moderators of the relationship between body image and self-esteem for African Americans. Sex Roles, 65, 619-631. https://doi.org/10.1007/s11199-011-9962-Z

Öztürk, F., Hazar, M., Beyleroğlu, M., \& Çelikağ, G. (2018). Beden eğitimi ve spor öğretmenliği öğretmen adaylarının sosyal fizik kaygıları ve beden imgesinden hoşnut olma düzeyleri. Türkiye Bilimsel Araştırmalar Dergisi, 3(1), 33-42. Retrieved from https://dergipark.org.tr/en/pub/tubad/issue/52293/684245

Rosenberg, M. (1965). Rosenberg self-esteem scale (RSE). Acceptance and commitment therapy. Measures package, 61(52), 18. https://doi.org/10.1037/t01038-000

Sarıbaş, Ç. Ç., Başgül, Ş. S., Cömert, I. T., \& Tutlu, M. G. (2019). 15-17 yaş elit ve amatör futbolcuların yeme tutumu, benlik saygısı ve kişilik özelliklerinin incelenmesi. Türk Sosyal Bilimler Araştırmaları Dergisi, 4(1), 34-46. Retrieved from http://tursbad.hku.edu.tr/tr/issue/44945/511087

Şimşek, Ö. F. (2007). Yapısal eşitlik modellemesine giriş (Temel ilkeler ve LISREL uygulamaları). İstanbul: Ekinoks.

Swami, V., Stieger, S., Haubner, T., \& Voracek, M. (2008). German translation and psychometric evaluation of the Body Appreciation Scale. Body Image, 5(1), 122-127. https://doi.org/10.1016/j.bodyim.2007.10.002

Tiggemann, M. (2005). Body dissatisfaction and adolescent self-esteem: Prospective findings. Body Image, 2(2), 129-135. https://doi.org/10.1016/j.bodyim.2005.03.006

Tyler, C., Johnston, C. A., Dalton III, W. T., \& Foreyt, J. P. (2009). Relationships between weight and body dissatisfaction, body esteem, and teasing in African American girls. Journal of Black Psychology, 35(1), 125-132. https://doi.org/10.1177\%2F0095798408323388

Tylka, T. L., \& Wood-Barcalow, N. L. (2015). The Body Appreciation Scale-2: item refinement and psychometric evaluation. Body image, 12, 53-67. https://doi.org/10.1016/j.bodyim.2014.09.006

Van Den Berg, P. A., Mond, J., Eisenberg, M., Ackard, D., \& Neumark-Sztainer, D. (2010). The link between body dissatisfaction and self-esteem in adolescents: Similarities across gender, age, weight status, race/ethnicity, and socioeconomic status. Journal of Adolescent Health, 47(3), 290-296. https://doi.org/10.1016/j.jadohealth.2010.02.004

\section{Copyrights}

Copyright for this article is retained by the author(s), with first publication rights granted to the journal.

This is an open-access article distributed under the terms and conditions of the Creative Commons Attribution license (http://creativecommons.org/licenses/by/4.0/). 